\title{
Autonomy and Identity in the Cities of Norman Italy, c. 1050-c.1200
}

DOI:

10.1111/hic3.12326

\section{Document Version}

Accepted author manuscript

Link to publication record in Manchester Research Explorer

\section{Citation for published version (APA):}

Oldfield, P. (2016). Autonomy and Identity in the Cities of Norman Italy, c. 1050-c.1200. History Compass, 14(8), 370-379. https://doi.org/10.1111/hic3.12326

\section{Published in:}

History Compass

\section{Citing this paper}

Please note that where the full-text provided on Manchester Research Explorer is the Author Accepted Manuscript or Proof version this may differ from the final Published version. If citing, it is advised that you check and use the publisher's definitive version.

\section{General rights}

Copyright and moral rights for the publications made accessible in the Research Explorer are retained by the authors and/or other copyright owners and it is a condition of accessing publications that users recognise and abide by the legal requirements associated with these rights.

\section{Takedown policy}

If you believe that this document breaches copyright please refer to the University of Manchester's Takedown Procedures [http://man.ac.uk/04Y6Bo] or contact uml.scholarlycommunications@manchester.ac.uk providing relevant details, so we can investigate your claim.

\section{OPEN ACCESS}




\section{Autonomy and Identity in the Cities of Norman Italy, c. 1050-c.1200 \\ Dr Paul Oldfield}

(*article accepted in June 2016 for publication in History Compass)

\section{Abstract:}

Understandings on the medieval cities of southern Italy and Sicily have for long been shaped by the so-called ósouthern Questionôand problematic comparisons with the cities of North and Central Italy. An over-arching conventional position emerged suggesting that the political and cultural dynamism of the cities of the South was drastically impaired by the arrival of the Normans and the creation of a monarchy. However, a corpus of revisionist, interdisciplinary work has been produced since the late-twentieth century. It has substantially reframed our perception of the types of autonomies and identities present within the cities of southern Italy and Sicily. This essay briefly tracks some of the most salient aspects of these recent historiographical developments.

The phase of the communes is rightly viewed as a golden era in Italian history. From the lateeleventh through to around the mid-fourteenth century, a variety of Italian urban communes and city-states pioneered new types of socio-political formations and commercial enterprise. They acquired radically new forms of autonomy and self-governance and vividly expressed their civic-consciousness across a variety of platforms. Through this, these cities became integral players in the history of medieval western Europe and have understandably received rich scholarly attention. ${ }^{1}$ They have been viewed as cradles of áivil societyô of a nascent democratic philosophy and of the Renaissance. ${ }^{2}$ But this was only half the picture ï quite literally. For these were the accomplishments of the cities of Central and Northern Italy. The 
urban centres of the South Italian mainland and Sicily did not experience similar transformation nor offer comparable contributions. Or so at least is the traditional dominant representation which was accorded to them by a less abundant body of historiography. However, from the last decades of the twentieth century scholars working on the urban history of medieval southern Italy (a term which I shall henceforth use to mean both the mainland and Sicily) have reconsidered the role of the regionôs cities. This has led to some important revisions to our understanding of these citiesôability to act autonomously and to articulate their own civic identities. This essay will, therefore, examine some of the key themes emerging from this recent corpus of work.

\section{North and South and the 'Southern Question'}

It is abundantly clear that the cities of the South operated within a vastly different political context from those of the Centre and North. Hastened by the ruptures associated with the socalled Investiture Contest, North and Central Italian cities saw the framework of public power backed by the Salian German emperors collapse from the mid-eleventh century. This left political vacuums to be filled, often by a combination of local bishops and elected officials who represented the urban community, or at least a proportion of it. Gradually, as the situation crystallised, many northern and central Italian cities found themselves, in Chris Wickhamôs recent and memorable phrase, óleepwalking into a new worldô of urban selfgovernance by the mid-twelfth century. ${ }^{3}$ The situation in the South developed along an alternate path. Here too from the mid-eleventh century there was a disintegration of preexisting political structures $\ddot{i}$ the Lombard principalities of Campania, Byzantine rule in Puglia and Calabria, Muslim rule on the island of Sicily $\ddot{i}$ and the opening up of yet more power vacuums. There are many explanations for this, but the main underpinning factor was 
the arrival of a series of military-adept migrant Norman aristocrats. By around 1100, almost the entire region (excluding the cities of Naples and Benevento) had been conquered by different Norman rulers, although southern Italy was far from politically unified. ${ }^{4}$ This would have to wait another thirty years, when in 1130 Roger II of Sicily, a son of a Norman immigrant, would combine Sicily and mainland southern Italy under one rule and raise its status to that of a monarchy. ${ }^{5}$ There was, inevitably, opposition, but this Kingdom of Sicily would become one of the most important and powerful monarchies in twelfth-century Europe until 1194 when it was conquered by the Staufen Emperor Henry VI. ${ }^{6}$ It would last, in one form or another, until the kingdom was absorbed into a unified Italy in 1861 during the Risorgimento.

The binary North-South transformation of Medieval Italy dovetailed neatly with historical narratives which developed in the nineteenth and twentieth centuries to explain the seemingly apparent difference between northern and southern Italy in the modern era. Numerous academics and other commentators tacked the so-called ósouthern Questionô(d́a questione meridionaleô), óroadly defined as the problem of southern political and economic áınderdevelopmentô relative to northern Italy. As a discourse of backwardness, and of a failure to resolve backwardnessô ${ }^{7}$ Many interpretations were invariably framed by broader agendas, often emerging from northern Italy, advocating intervention and reform in the South in order to better assimilate it within the new Italian nation-state which had been formally constructed by 1870 . Some were founded on a deeper moral censure which targeted the apparent uncivilised socio-cultural character of South Italians, which in turn was shaped by seemingly corrupt political regimes and a sinister natural climate and landscape. ${ }^{8}$ In this sense, the South and its development seemed to fall beyond the very frontiers of Europe, its traditions and past deemed not fully part of Europeôs. ${ }^{9}$ Among the many criticisms of the 
Southôs development, an absence of a sufficiently robust civic spirit and the domination of foreign powers were held to be important factors. Such interpretations influenced understandings of the cities of Norman Italy during the twentieth century. The óforeignô Normans ultimately played a damaging role, for their conquests were held to have stunted the types of urban autonomies emerging at the same time in central and northern Italy. And for all the acknowledgement of its impressive authority, the Kingdom of Sicily, founded in 1130, was viewed as consolidating a repressive grip over its cities through its centralised administrative superstructure. ${ }^{10}$ Some historians, such as Francesco Carabellese with his work (published in 1905) on the Pugliese cities, attempted to work against this in order to find evidence for urban autonomy comparable to that found in the North. ${ }^{11}$ Later, Francesco Calassô̂ important work on urban liberties (published in 1929), produced some nuanced conclusions that would be developed further by historians in the later-twentieth century working within a different academic milieu. ${ }^{12}$ Calasso found that the Normans, in relation to the cities of southern Italy, álid not develop a programme of liberty, nor of restraint, but rather they realized, bowing to the pressure of local elements, a system of guarantees. $\hat{0}^{3} \mathrm{He}$ also argued against the tendency to resort to generalizations about the status of southern Italian cities in the Norman period. ${ }^{14}$ But these, and other, studies of the early-twentieth century often focused primarily on political, institutional and legal history. And, therefore, despite their valuable analyses, in a climate that promoted an implicit assumption that the South should be like the North (or at least measured by the standards of the latter), the medieval cities of southern Italy $\ddot{i}$ in terms of political or legal innovation $\ddot{i}$ usually came up short. On the other hand, the Storia del Regno di Napoli (published in 1923), the influential work of the philosopher-historian Benedetto Croce (himself a proud Neapolitan), produced a radical deconstruction of South Italian history as a whole. But in doing so it also highlighted the failure of a national spirit to mature under the Norman monarchy and the latterôs 
suppression of cities, which Croce saw as the driving forces in the history of the Centre and the North. ${ }^{15}$ The deleterious impact of limited urban political autonomy in the South, stemming from the arrival of the Normans, became something of an orthodoxy. Its significance is often emphasised in modern works on the roots of civic traditions in Modern Italy. In the early 1990s, for instance, Robert D. Putnamôs important study, which drew on surveys of medieval Italy which were interested primarily with northern Italy, accepted the Norman Kingdom of Sicily as a mix of the ớfeudalô the óbureaucraticô and the ábsolutistô ${ }^{16}$ A stark dichotomy was presented underlined by the Southôs passivity: đ́n the North, the people were citizens; in the South, they were subjects. $\hat{o}^{7}$

Until revisionist work began in the last few decades of the twentieth century, there has been an evident irony in the respective modern historiographical representations of the cities of northern and southern Italy during the Central Middle Ages. It is an irony formed around a core component of the long-standing approach to the Southern Question: South Italian history was often dealt with as a collective entity. The same collective approach was largely applied to its cities, and the nature of urban autonomy and identity, in the Norman era, subsumed under the unifying umbrella of the Norman monarchy. So, while the Centre and North has been viewed as a complex mosaic of individually distinct urban centres in the Middle Ages, the Southôs cities were rarely afforded the same sort of nuanced treatment. As Lucy Riall remarked, revisionist approaches encourage áıs to question and, even, abandon our perception of ósouthern Italyô [é ], as a separate and collective identity.ôInstead, we should consider the notion of multiple societies, cultures and economies in the South, just as has been the case for the Centre and North. ${ }^{18}$ The irony then, is that, arguably, the political and socio-cultural background of many medieval northern Italian cities was much more homogenous than those of a region which incorporated Lombard, Greek, and Arabic 
traditions which were embedded in cities as different from each other as Salerno, Naples, Bari, Messina and Palermo. Moreover, far from a marginalised region, southern Italy (and its cities) was located at the crossroads of the Mediterranean. It thus shared some of the most profound transformations and experiences which were common to the wider medieval world.

\section{Revisionism and New Approaches:}

Much recent revisionism on urban autonomy and identity in Norman Italy has developed, therefore, through a more nuanced optic which recognises the Southô heterogeneity and complexity more fully. And much of this recent work acknowledges the flexibility, ambiguity and inconsistency of medieval urban terminology (that is, how officials, structures and procedures were labelled) which was utilised in the cities of southern Italy, and thus rethinks what these terms might signify. The city has been afforded its own place, outside the shadow of an authoritarian ớoreignôpresence, be that presence either eleventh-century conquering Norman warriors, or a twelfth-century monarchy. For instance, it is the case that castles rather than communal palaces represented the main secular buildings in many South Italian cities. But scholars are rethinking the fundamental functions of castles, particularly in urban settings. Their multivalent role could encompass dominance, justice, protection, urban solidarity and a symbolic focal point for communication between communities and higher authority. ${ }^{19}$ Indeed, medieval rulership itself (including the monarchy in Sicily) is now increasingly viewed as inter-mixing more flexible forms of control; forms which some scholars label as hard power (military coercion, economic control, centralised administrative supervision and so on), and soft power (negotiation and cultural co-option). ${ }^{20}$ It is a model rooted in an increased awareness of the limitations of the reach of medieval monarchy. Medieval urban communities, including those of southern Italy, have, therefore, been re- 
examined within the broader spectrum of inter-relationships allowed by this understanding of medieval governance. As such, greater agency has been conferred onto cities, as the ruling authority often needed to understand and be seen (at least to some extent) to respect the socio-cultural practices of their subjects in order to effectively co-opt them. This broader interpretative spectrum also encourages the historian to draw on a wider body of interdisciplinary material and methodologies. One of the first works to adopt such an interdisciplinary approach with great success for a South Italian city was Paolo Deloguôs multilayered monograph on Salerno. ${ }^{21}$ It used a range of textual and topographic evidence to show how a Salernitan urban identity was constructed and how the cityôs elites negotiated the process of Norman conquest in the 1070s. Deemed a q́rototype of the new attitudeôin South Italian historiography, numerous works on the cities of Norman Italy have followed suit. ${ }^{22}$ They were aided by the expansion of the university system in southern Italy in the 1970s and 1980 s. $^{23}$ In this space here we can only consider a relatively small sample of this more recent body of research. Some of it research continued to concentrate on, and revise, notions of political autonomy. Two important studies emerged in 1979 from the third annual conference organised by the Centro di Studi Normanno-Svevi at Bari. One, by Paolo Delogu, emphasised the rather antagonistic interactions between cities and Normans across the whole Norman period, and in so doing highlighted the citiesôpotential for action and opposition. ${ }^{24}$ The other, by Jean-Marie Martin, considered the relationships between the cities of Puglia and the first monarch, Roger II. Martin found that, while the cities were denuded of real political authority, a compromise bargain was nevertheless struck which conferred a measure of liberty on the cities because the monarchyôs administrative structures were incapable of tighter control. ${ }^{25}$ More recently, there has been a tendency to develop this further and suggest that cities and Norman rulers were far from natural antagonists. Contributions by Donald Matthew and Chris Wickham on Salerno in the twelfth century present a picture of a city that 
was able to preserve an important set of liberties under Norman rule, allowing it significant self-regulatory powers. Moreover, Salernoôs urban government appears to have been formed around vertical grades of authority, with a communal base, which meant it was easier to integrate into the structure of the new Norman monarchy. Hence, according to Matthew, the Salernitans could be labelled ósemper fidelesô(álways loyalô) to higher authority. ${ }^{26}$ Building on this position, Oldfieldôs comparative study of the mainland cities of southern Italy in the Norman period emphasised the communal element present in many of the cityôs urban governments. It also argued for the complexity of urban communities ï such as Bari, Capua, Salerno, Trani, Troia $\ddot{i}$ and that they were reluctant to reject Norman rule, not because they feared it but because the latter actually offered de-facto forms of freedom in the areas of urban life which mattered most: the preservation of much-cherished local customs, and the performance of equitable justice carried out by native officials within the city itself and following norms dictated by urban traditions. The cities might not have enjoyed the sort of political independence achieved by their North Italian counterparts, but each individually had the power to negotiate in areas of concern to them, and to establish their own unique relationships with the Norman elite. Thus modern scholars might have overemphasised the importance of political power based on modern paradigms of governance. ${ }^{27}$ Moreover, other recent studies encourage us not to follow a purely dialectical approach to the interrelationship between the cities and their Norman rulers. There were numerous interest groups within cities which had multiple affinities, the likes of religious establishments, lay religious associations (particularly at Naples and Benevento) and aristocrats. ${ }^{28}$ Rosanna Alaggioôs recent study, for example, has tracked the existence of urban fiefs in Puglia, and the enmeshing of cities within a feudal network. The holders of these fiefs represented another layer, perhaps also a mediating force, between city and Norman elite. ${ }^{29}$ 
The idea of multiple urban affinities $\ddot{i}$ which has a strong tradition in the historiography of the North and Central Italian cities $\ddot{i}$ suggests that a series of affective conduits were necessary to bind the diversity of the city together. This returns us to the notion of forms of soft power and their importance. It also requires a more overt inter-disciplinary approach, exploring different bodies of evidence and placing them into new relationships. In this context, an important study by Giovanni Vitolo explored civic consciousness in medieval southern Italy. ${ }^{30}$ While he concluded that the Norman monarchy ultimately became the essential political and cultural reference point for cities, most of which, in the twelfth century, lacked their own forms of civic historiography (the sort of urban chronicles and annals produced in central and northern Italy), Vitolo also highlighted some important channels through which an urban identity was promoted in the eleventh and twelfth centuries. These were through urban panegyric (and the so-called laus urbis literary genre), through urban saints cults, and the presence of private towers and noble consorteria (factions, cliques).

Several studies have further explored these three reference points (panegyric, sanctity, and, in expanding out from Vitoloôs private towers, the urban landscape) for urban identity. In the eleventh and twelfth centuries, short passages of urban panegyric were produced, in varying forms, on several cities such as Amalfi, Benevento, Capua, Catania, Messina, Naples, Palermo, Salerno and Syracuse. Some of the praise within them might focus on the cityô landscape, ancient foundation and history, commerce, deeds of its inhabitants, and the cityô religiosity. If some were produced by those who dominated the cities for agendas which served political purposes, they showed how important cities were to them, and often reflected important markers of urban identity and pride. ${ }^{31}$ Saints cults have offered a particularly rich entry point into urban society, especially with the growing recognition from the latertwentieth century of the importance of hagiographical texts and a greater appreciation of the 
ways a lay urban audience participated in various aspects of a cult. This topic has been explored extensively and fruitfully for cities across Europe, and southern Italy has been no exception. ${ }^{32}$ These studies show that several South Italian saints cults were revived or created during the Norman period. It has been suggested that they represented ómore noncontroversial foci for civic prideôfollowing the loss of formal political autonomy to the Normans. ${ }^{33}$ This may indeed have played a part. However, more compelling causes might be found in new lay devotional practices which transformed the visage of many South Italian cities in the eleventh and twelfth centuries. And also in the effects of growing urbanisation, commercialisation and mobility, which brought renewed inter-urban competition. Thus, Bari famously acquired the relics of St Nicholas of Myra in 1087, and other cults were revived or established: St Matthew at Salerno (c.1080 ), St Nicholas the Pilgrim at Trani in the 1090s, St Cataldus at Taranto (c.1090sx1150s), St Agatha at Catania (from 1126), and several cults at Benevento in the early decades of the twelfth century. These cults empowered their urban communities, conferring a shared identity and pride (which often generated or reflected rivalry with other cities over the superiority of their respective patron saints), and drawing in wealth and investment into cities. ${ }^{34}$

Spirituality and the performance of faith, of course, ran deep in medieval urban society. Nino Zchomelidseôs work on South Italian liturgical scrolls has shown how ecclesiastical art and ritual promoted civic identities, and how they intersected in a dynamic way. ${ }^{35}$ This approach fits with a growing interest in how urban identity and power could also be projected through symbols in the landscape and the arrangement of urban space. Recent research drawing on methodologies from cultural geography has considered the urban topography and material culture within South Italian cities in this context. ${ }^{36}$ Caterina Lavarraôs works, for instance, have explored the multivalent meanings behind the ordering of processional rituals, 
particularly triumphal entries and acts of punishment, throughout the urban landscape. ${ }^{37}$ As such, these performative events reflected a mutual discourse between the city and the subject of the processions, a king entering Naples or Palermo, a pope arriving at Benevento, a highprofile offender being paraded through the streets of Messina:

The solemn rituals of reception were extraordinary instruments of interaction between people or groups of people, but above all of communication, in as much as they transmitted non-verbal messages, the content of which was mediated by symbolic elements intelligible to all the participants, protagonists or viewers (the public), and they lent themselves to be used for the representation of power-relationships, demonstrating a highly political character. ${ }^{38}$

Unsurprisingly, the symbolic space of the city of Palermo, which became the áapitalôof the Kingdom of Sicily, has received a great deal of recent attention. ${ }^{39}$ Here, the dominance of the monarchy, through its material presence (royal palaces and religious complexes) distinguished this city from all others in the realm. These royal buildings dominated, but were detached from, the city. They arguably showed the monarchyôs desire, embodied in a physical form, to separate itself from the urban community, which was also apparent on the mainland where the various bargains struck with cities ensured limited royal intervention in return for urban loyalty. ${ }^{40}$ Indeed, according to Laura Sciascia, medieval Palermo represented a veritable stage on which to project political authority, with protagonists (kings), directors (royal advisors), antagonists (the City itself), and a series of scene changes traversing dightô (coronations) and óriefô(royal funerals, coup dđ̂tats). ${ }^{41}$

A greater understanding of the materiality of the urban landscape of the cities of Norman Italy, aided by ongoing archaeological work, has, therefore, made a significant contribution in building a more layered picture of the society and culture within those cities. ${ }^{42}$ This of course includes a more nuanced appreciation of South Italian urban art. Jill Caskeyôs examination of art and patronage in medieval Amalfi is founded on a view of the alterity of Amalfitan culture. The city and its region developed a distinctive artistic style linked to its commercial 
activities and which Caskey labels the óArt of Mercatantiaô Above all, Caskey argues for áhe possibility of sustained cultural continuity on a local levelôas evidenced through a system of local art and patronage that should not be homogenised under the catch-all categories of royal or institutional art which have tended to dominate the scholarship of South Italian Art History. ${ }^{43}$ On an economic level, Patricia Skinnerôs recent book on Amalfi supports this position of distinctive urban pathways. For it argues that the unusual commercial vibrancy of Amalfi continued and adapted under the Norman monarchy in different forms, driven by individual, local agents, and not primarily by a centralised authority. ${ }^{44}$ The Norman monarchy might, as David Abulafia comprehensively demonstrated, have óut-sourcedômuch of its export-import trade to Pisan and Genoese merchants, but individual South Italian cities developed their own innovative responses to the new situation. ${ }^{45}$ Studies on Naples, for example, show a óociety in transformationô in the later-twelfth century. ${ }^{46} \mathrm{New}$ markets opened up via the Genoese and Pisan trading networks, port facilities were improved, and the Neapolitan economy was increasingly monetized under the direction of new urban kingroups. $^{47}$

All of this brings us back full circle to what Caskey called the óphantom presenceô of the Southern Question and to the ongoing imperative to rethink it in order to discover the óich local contextsôthat undoubtedly existed in southern Italy and its cities. ${ }^{48}$ There is, of course, much work still to be done, but it appears that these óich local contextsôare indeed being found and are allowing researchers to examine the cities of Norman Italy on their own terms. ${ }^{49}$ This in turn ensures that meaningful comparisons can be made with the cities of the rest of the Italian peninsula, without undermining the evident differences between the North and South or diminishing the remarkable accomplishments of the medieval cities of North 
and Central Italy. Even more importantly, it affords southern Italyôs cities their own place within Europeôs urban history of the Central Middle Ages. 
Bibliography:

Abualfia, D., The Two Italies: Economic Relations between the Norman Kingdom of Sicily and the Northern Communes (Cambridge: Cambridge University Press, 1977).

Alaggio, R., ÓFonti e prospettive metodologiche per la storia delle citta nel Mezzogiorno medievaleô in T. Budriesi and A. Laura (eds), Cultura cittadina e documentazione: formazione e circolazione di modelli: Bologna, 12-13 ottobre 2006 (Bologna: ClueB, 2009), 231-53 [also available at http://www.rmoa.unina.it/13/1/RM-Alaggio-Fonti.pdf].

Alaggio, R., đ́l processo di feudalizzazione della società. I contesti urbani della Pugliâ̂ in G. Galasso (ed.), Alle origini del dualismo italiano. Regno di Sicilia e Italia centrosettentrionale dagli Alatvilla agli Angiò (1100-1350 (Soveria Mannelli: Rubbettino, 2014), $137-76$.

Barton, S., đatrons, pilgrims and the cult of saints in the medieval kingdom of Leónô in J. Stopford (ed.), Pilgrimage Explored (Woodbridge: York Medieval Press, 1999), 57-77.

Bates, D., The Normans and Empire (Oxford: Oxford University Press, 2013).

Brown, T. S., ÓThe Political Use of the Past in Norman Sicilyô in P. Magdalino (ed.), Perceptions of the Past in Twelfth-Century Europe (London: Hambledon Press, 1992), 191210. 
Calasso, F., La legislazione statutaria dell'Italia meridionale: le basi storichi; le libertè cittadine dalla Fondazione del regno all'epoca degli statuti (Rome: A. Signorelli, 1929)

Carabellese, F., L'Apulia ed il suo commune nell'Alto Medio Evo (Bari: Commissione provinciale di archeologia e storia patria, 1905).

Caskey, J., Art and Patronage in the Medieval Mediterranean. Merchant Culture in the Region of Amalfi (Cambridge: Cambridge University Press, 2004).

Cioffari, G., Storia della basilica di S. Nicola di Bari. I. L'epoca normanno-sveva (Bari: Centro studi nicolaiani della Basilica di S. Nicola, 1984).

Coulson, C., Castles in Medieval Society: Fortresses in England, France, and Ireland in the Central Middle Ages (Oxford, 2003).

Croce, B., History of the Kingdom of Naples, trans. H. S. Hughes (Chicago: University of Chicago Press, 1970).

Delogu, P., Mito di una città meridionale (Salerno, secoli VIII-XI) (Naples: Liguori, 1977).

Delogu, P., đ́ normanni in città: schemi politici ed urbanisticiô in Società, potere e popolo nell'età di Ruggero II. Atti delle terze giornate normanno-sveve, Bari, 23-25 maggio 1977 (Bari: Dedalo, 1979), 173-205. 
Efthymiades, S., đ́ôOrient en occident mais étranger aux deux mondes. Messages et renseignements tirés de la vie de Saint Nicolas le Pèlerin (BHL 6223)Q̂ in E. Cuozzo et al. (eds), Puer Apuliae: mélanges offerts à Jean-Marie Martin, vol. 1 (Paris: ACHCByz, 2008), 207-23.

Feniello, A., óMercato della terra a Napoli nel XII secoloQ̂ in E. Cuozzo et al. (eds), Puer Apuliae: mélanges offerts à Jean-Marie Martin, vol. 1 (Paris: ACHCByz, 2008), 291-318.

Feniello, A., Napoli. Società ed economia, 902-1137 (Rome: Istituto storico italiano per il Medio Evo, 2011).

Feniello, A., óAlle origini di Napoli capitale: il porto, la terra, il denaroQ̂ Mélanges de l'Ecole française de Rome. Moyen Âge, 124 (2012), 567-84.

Fiorella, D., đ́a presenza degli ordini monastico-cavallereschi a Barlettâ̂ in M. Oldoni (ed.), Tra Roma e Gerusalemme nel Medioevo. Paessaggi umani ed ambientali del pellegrinaggio meridionale, vol. 2 (Salerno: Laveglia, 2005), 409-33.

Fiorillo, R. and Lambert, C. (eds), Medioevo letto, scavato, rivalutato: studi in onore di Paolo Peduto (Borgo S. Lorenzo: All'Insegna del Giglio, 2012).

Frank, T., Studien zu Italienischen Memorialzeugnissen des XI. und XII. Jahrhunderts (Berlin; de Gruyter, 1991). 
Galasso, G., óconsiderazioni intorno alla storia del Mezzogiorno dôtaliậ in idem. Mezzogiorno medievale e moderno (Turin: Giulio Einaudi, 1965), 13-59.

Galasso, G., đ́refazioneô in G. Galasso (ed.), Alle origini del dualismo italiano. Regno di Sicilia e Italia centro-settentrionale dagli Alatvilla agli Angiò (1100-1350 (Soveria Mannelli: Rubbettino, 2014), 7-10.

Galdi, A., ól santo e la città: il culto di S. Matteo a Salerno tra X e XVI secoloQ̂ Rassegna storica salernitana, 25 (1996), 21-92.

Galdi, A., Santi, territori, potere e uomini nella Campania medievale (secc. XI-XII) (Salerno: Laveglia, 2004).

Geary, P. J., Furta Sacra: Thefts of Relics in the Central Middle Ages (Princeton: Princeton University Press, revised edn, 1990).

Golinelli, P., Città e culto dei santi nel medioevo italiano (Bologna: Clueb, new edn, 1996).

Haverkamp, A., đ̛Heilige Städte im hohen Mittelalterô in F. Graus (ed.), Mentalitäten im Mittelalter. Methodische und inhaltliche Probleme (Sigmarigen: J. Thorbecke, 1987), 119-56.

Head, T., điscontinuity and Discovery in the Cult of Saints: Apulia from Late Antiquity to the High Middle Agesô Hagiographica, 6 (1999), 171-211 
Houben, H., Roger II of Sicily. A Ruler between East and West, trans. G. A. Loud and D. Milburn (Cambridge: Cambridge University Press, 2002).

Hyde, J. K., Society and Politics in Medieval Italy: the Evolution of the Civil Life, 1000-1350 (London: MacMillan, 1973).

Intorcia, G., La comunità beneventana nei secoli XII-XVIII. Aspetti istituzionali. Controversie giurisdizionali (Naples: Edizioni scientifiche italiane, 1996).

Jamison, E. M., óThe Noman Administration of Apulia and Capua more especially under Roger II and William I, 1127-1166ô Papers of the British School at Rome 6 (1913), 211-481 [reprinted as a separate volume, Aalen: Scientia, 1987]

Jones, P., The Italian City-State: from Commune to Signoria (Oxford: Clarendon Press, 1997).

Lavarra, C., đ́Rituali dâssclusione e spazio sociale nel Mezzogiorno normannoQ̂ in C. D. Fonseca and V. Sivo (eds), Studi in onore di Giosuè Musca (Bari: Dedalo, 2000), 269-95.

Lavarra, C., Mezzogiorno normanno. Potere, spazio urbano, ritualità (Galatina: Congedo, 2005).

Lilley, K. D., City and Cosmos: the Medieval World in Urban Form (London: Reaktion, 2009) 
Limone, O., Santi monaci e santi eremeti; alla ricerca di un modello di prefazione nella letteratura agiografica dell'Apulia normanna (Galatina: Congedo, 1988).

Limone, O., ál patrimonio letterario agiografico nella Puglia nei secoli XI-XII: quindici anni di studiô Hagiographica, 15 (2008), 257-72.

Loud, G. A., đ́olitics, piety and ecclesiastical patronage in twelfth-century BeneventoQ̂ in E. Cuozzo and J-M. Martin (eds), Cavalieri alla conquista del Sud. Studi sull'Italia normanna in memoria Léon-Robert Menager (Bari, 1998), 283-312 [reprinted in idem, Montecassino and Benevento in the Middle Ages (Aldershot: Ashgate, 2000).

Loud, G. A., The Age of Robert Guiscard: Southern Italy and the Norman Conquest (Harlow: Longman, 2000).

Marongiu, A., óA Model State in the Middle Ages: the Norman and Swabian Kingdom of Sicilyô Comparative Studies in Society and History, 6 (1963-4).

Martin, J-M, đ́es Communautés dôhabitants de la Pouille et leur rapports avec Roger IIô in in Società, potere e popolo nell'età di Ruggero II. Atti delle terze giornate normanno-sveve, Bari, 23-25 maggio 1977 (Bari: Dedalo, 1979), 73-96.

Matthew, D., óSemper fideles. The Citizens of Salerno in the Norman Kingdomô in P. Delogu and P. Peduto (eds), Salerno nel XII secolo. Istituzioni, società, cultura. Atti del convegno internazionale [June 1999] (Salerno: Centro Studi salernitani đ́Raffaele Guarigliaô 2004), 2745. 
Menant, F., L'Italie des communes (1100-1350) (Paris: Belin, 2005).

Moe, N., The View from Vesuvius: Italian Culture and the Southern Question (Berkeley: University of California Press, 2002).

Musca, G. (ed.), Itinerari e centri urbani nel Mezzogiorno normanno-svevo: atti delle decime giornate normanno-sveve, Bari, 21-24 ottobre 1991 (Bari: Dedalo, 1993).

Nef, A., Conquerir et Gouverner. La Sicile Islamique aux XI et XII siècles (Rome: École française de Rome).

Nef, A., (ed.), A Companion to Medieval Palermo. The History of a Mediterranean City from 600 to 1500 (Leiden: Brill, 2013).

Nye, J. S., Soft Power: The Means to Success in World Politics (New York: PublicAffairs, 2004).

Oldfield, P., City and Community in Norman Italy (Cambridge: Cambridge University Press, 2009).

Oldfield, P., Sanctity and Pilgrimage in Medieval Southern Italy, 1000-1200 (Cambridge: Cambridge University Press, 2014). 
Oldfield, P., óThe Bari Charter of Privileges of 1132: articulating the culture of a new Norman monarchyQ̂ Historical Research, 88 (2015), 577-598.

Oldfield, P., Urban Panegyric and the Transformation of the Medieval City, 1100-1300 (forthcoming).

Peduto, P., et al., đ́n accesso alla storia di Salerno. Stratigrafie e materiali dellôrea palaziale longobardaQ̂ Rassegna Storica Salernitana,10 (1988), 9-63.

Pertusi, A., óAi confini tra religione e politica. La contesa per le reliquie di S. Nicola tra Bari, Venezia e GenovaQ̂ Quaderni medievali 5 (1978), 6-56.

Putnam, R. D., Making Democracy Work. Civic Traditions in Modern Italy (Princeton: Princeton University Press, 1993).

Rees-Jones, S., áCities and their Saints in England, circa 1150-1300: the development of bourgeois values in the cults of Saint William of York and Saint Kenelm of Winchcombeô in C. Goodson, A. E. Lester and C. Symes (eds), Cities, Texts and Social Networks, 400-1500. Experiences and Perceptions of Medieval Urban Space (Farnham: Ashgate, 2010), 193-213

Reynolds, S., Kingdoms and Communities in Western Europe, 900-1300 (Oxford: Clarendon Press, $2^{\text {nd }}$ edn, 1997)

Riall, L., ÓWhich Road to the South: Revisionists revisit the MezzogiornoQ̂ Journal of Modern Italian Studies, 5 (2000), 89-100. 
Sciascia, L., đ́alermo as a Stage for, and a Mirror of, Political Developments from the $12^{\text {th }}$ to the $15^{\text {th }}$ Centuryô in A. Nef (ed.), A Companion to Medieval Palermo. The History of a Mediterranean City from 600 to 1500 (Leiden: Brill, 2013), pp. 299-323.

Skinner, P., Medieval Amalfi and its Diaspora, 800-1250 (Oxford: Oxford University Press, 2013).

Thompson, A., Cities of God. The Religion of the Italian Communes 1125-1325 (University Park, Pa: Pennsylvania State University Press, 2005).

Tramontana, S., óspazi urbani e identità cittadina in Sicilia. Note e riflessioni per i secoli XIXIIQ̂ Bullettino dell'Istituto storico italiano per il medio evo, 110 (2008), 129-96.

Vitolo, G., Città e coscienza cittadina nel Mezzogiorno medievale (secc. IX-XIII) (Salerno: Laveglia, 1990).

Vitolo, G., đ́sperienze religiose nella Napoli dei secoli XII-XIVQ̂ in G. Rossetti and G. Vitolo (eds), Medioevo Mezzogiorno Mediterraneo - studi in onore di Mario del Treppo vol. 1 (Naples: Liguori, GISEM, 2000), 3-34.

Vuolo, A., ÓAgiografia benevantanaQ̂ in G. Andenna and G. Picasso (eds), Longobardia e longobardi nell'Italia meridionale. Le istituzioni ecclesiastiche (Milan: Vita e pensiero, 1996), 199-237. 
Webb, D, Patrons and Defenders. The Saints in the Italian City States (London: Tauris, 1996).

Wickham, C., ácity society in twelfth-century Italy and the example of Salernoôin P. Delogu and P. Peduto (eds), Salerno nel XII secolo. Istituzioni, società, cultura. Atti del convegno internazionale [June 1999] (Salerno: Centro Studi salernitani đ́Raffaele Guarigliaô 2004), 1226.

Wickham, C., Sleepwalking into a New World: the Emergence of Italian City Communes in the Twelfth Century (Princeton: Princeton University Press, 2015).

Zchomelidse, N., Art, Ritual, and Civic Identity in Medieval Southern Italy (University Park, Pa: Pennsylvania State University Press, 2014). 
${ }^{1}$ See for example the key studies by Wickham, Sleepwalking; Jones, Italian City-State; Menant, L'Italie.

${ }^{2}$ Hyde, Society and Politics; Wickham, Sleepwalking, 1-20.

${ }^{3}$ Wickham, Sleepwalking, 161-205.

${ }^{4}$ See Loud, Age of Robert Guiscard.

${ }^{5}$ On the creation of the kingdom: Houben, Roger II, 50-75

${ }^{6}$ As a result, from the arrival of the first Normans in c. 1000 to the conquest of the Staufens in 1194, the region is often labelled as Norman Italy.

${ }^{7}$ Riall, óWhich Road to the Southô 90.

${ }^{8}$ See generally Moe, View from Vesuvius.

${ }^{9}$ See Galazzo, óprefazioneô 9.

${ }^{10}$ Marongiu, óA Model StateQ̂ 307-20; Jamison, óNorman Administrationô p. 235.

${ }^{11}$ Carabellese, L'Apulia ed il suo commune.

${ }^{12}$ See for example the study in the late-1970s by Martin, Les Communautésô 73-96.

${ }^{13}$ Calasso, La legislazione statutaria , p. 82

${ }^{14}$ Calasso, La legislazione statutaria, p. 115.

${ }^{15}$ Croceôs work is examined in an important survey by G. Galasso, óconsiderazioniô For an English translation of Croceôs Storia del Regno see: Croce, History.

${ }^{16}$ Putnam, Making Democracy, 123.

${ }^{17}$ Putnam, Making Democracy, 130.

${ }^{18}$ Riall, óWhich Road to the Southô 99.

${ }^{19}$ See, for example, Coulson, Castles.

${ }^{20}$ See, for example, Reynolds, Kingdoms and Communities and Bates, Normans and Empire, 3-4, 18-23. On Q́oft powerQ̂ see the seminal works of J. S. Nye, for example his Soft Power.

${ }^{21}$ Delogu, Mito di una città.

${ }^{22}$ For discussion of the importance of Deloguôs work and a survey of some of the main methodological approaches taken on medieval South Italian cities see Alaggio, ófonti e prospettive metodologicheô 231-53 (243-4 for Deloguôs work). See also the different methodological approaches taken by contributors in the volume edited by Musca, Itinerari e centri urbani, which offers essays on 20 cities in medieval southern Italy and Sicily.

${ }^{23}$ Alaggio, ófonti e prospettive metodologicheQ̂ 242-3. 
${ }^{24}$ Delogu, á normanni in cittàô 173-205.

${ }^{25}$ Martin, đ́es Communautésô 73-96.

${ }^{26}$ Matthew, óSemper fidelesô 27-45; Wickham, ócity Societyô 12-26.

${ }^{27}$ Oldfield, City and Community. See also Oldfield, óBari Charterô 577-598. Benevento, which remained an enclave under papal rule, developed more open forms of governmental and political independence in the twelfth century, above all with the implementation of urban consuls, officials prominent in north Italian communes: see Intorcia, La comunità beneventana and Loud, đ́oliticsQ̂ 283-312

${ }^{28}$ For literature on South Italian confraternities see: Frank, Studien zu Italienischen Memorialzeugnissen, especially 73-94, 156-79; Vitolo, đ́Esperienze religioseô 3-34.

${ }^{29}$ Alaggio, ál processo di feudalizzazioneâ 137-76.

${ }^{30}$ Vitolo, Città e coscienza cittadina. On urban historical writing see also Brown, đoolitical Use of the Pastô 195-8.

${ }^{31}$ On the importance of urban panegyric see Oldfield, Urban Panegyric.

${ }^{32}$ For examples from elsewhere in Europe, see for instance: Barton, óPatronsô 57-77; Haverkamp, óHeilige StädteQ̂ 119-56; Rees-Jones, óCitiesô 193-213; Thompson, Cities of God; Webb, Patrons and Defenders; Golinelli, Città e culto.

${ }^{33}$ Brown, đ́olitical Use of the Pastô197-8.

${ }^{34}$ Cioffari, Storia; Pertusi, óAi confini tra religione e politicaô 6-56; Geary, Furta Sacra, 94-103; Limone, ól patrimonio letteraioQ̂ 257-72; Galdi, đ́l santo e la cittàô 21-92, and for other Campanian saints cults: Galdi, Santi; Efthymiades, óô̂rient en occidentô 207-23; Head, óDiscontinuity and Discoveryô 171-211; Limone, Santi; Oldfield, Sanctity and Pilgrimage, 95-106, 153-63; Vuolo, óAgiografia benevantanaô 199-237.

${ }^{35}$ Zchomelidse, Art, Ritual, and Civic Identity; while this study focuses primarily on the thirteenth century, it also looks back to the twelfth and the authorô methodology is certainly applicable to this earlier period.

${ }^{36}$ On the application of cultural geography to the medieval city see most recently Lilley, City and Cosmos.

${ }^{37}$ See the three essays of Lavarra in Mezzogiorno normanno and Lavarra, óRituali dôsclusione e spazio socialeô 269-95.

${ }^{38}$ Lavarra, Mezzogiorno normanno, 47

${ }^{39}$ See the volume edited by Nef, Companion to Medieval Palermo.

${ }^{40}$ See for example Tramontana, óspazi urbaniô 129-96.

${ }^{41}$ Sciascia, đ́PalermoQ̂ 299-323. 
${ }^{42}$ See for example Fiorella, đá presenza degli ordini monastico-cavallereschiô 409-33 which shows how Barlettaôs built environment changed in conjunction with the development of the Crusading movement; Peduto et al., Ún accesso alla storia di SalernoQ̂ 9-63; and the contributions in Fiorillo and Lambert (eds), Medioevo letto, scavato, rivalutato.

${ }^{43}$ Caskey, Art and Patronage, 15-18 (quote at 16).

${ }^{44}$ Skinner, Medieval Amalfi. Amedeo Feniello: Napoli. Società ed economia, 902-1137 (Rome, 2011) and also his óMercato della terra a Napoli nel XII secoloôin Puer Apuliae, pp. 291-318; óAlle origini di Napoli capitale: il porto, la terra, il denaroô Mélanges de lâEcole française de Rome. Moyen Âge 124 (2012), 567-84.

${ }^{45}$ D. Abualfia, The Two Italies: Economic Relations between the Norman Kingdom of Sicily and the Northern Communes (Cambridge: Cambridge University Press, 1977); Feniello, óMercato della terra a Napoliô 291-318 (at p. 303).

${ }^{46}$ Feniello, óMercato della terra a Napoliô 317. See also other works by the same author, especially: Napoli. Società ed economia, and also his óAlle origini di Napoli capitale: il porto, 567-84.

${ }^{47}$ Feniello, óMercato della terra a Napoliô pp. 301-03, 317. For more studies on the economy of the cities of Norman Italy see the contributions in the aforementioned Musca (ed.), Itinerari e centri urbani.

${ }^{48}$ Caskey, Art and Patronage, 18.

${ }^{49}$ Nef, Conquerir et Gouverner, 567 refers to órous noirsô in the history of Norman Sicilyôs cities, and particularly its Arab-Islamic urban communities. 